Institute of $\mathbf{F}_{\text {ood and }} \mathbf{A}$ gricultural $\mathbf{S}_{\text {ciences }}$

\title{
Peanut Variety Protection ${ }^{1}$
}

\section{E. B. Whitty ${ }^{2}$}

Peanut farmers may be tempted to save seed from their own fields for planting next year because of changes in the 2002 Farm Bill. There are quality and economic risks to using saved seed, but growers, seed producers, seed processors, seed dealers, and all others that deal with peanut seed should also be aware of the provisions of the Plant Variety Protection Act and of utility patents that may relate to the production and sale of peanut seed. These provisions are based on federal laws and apply not just to peanuts, but to varieties of any plant that have such protection under either or both set(s) of regulations. These regulations are used extensively, as most recentlyreleased varieties have been registered for plant variety protection. Florunner may be the only peanut variety available that is not covered by the Plant Variety Protection Act. An increasing number of varieties of various crops contain genes that are covered by utility patents. Variety protection and utility patents are two separate issues, but have similar effects on seed production and sale or use.

The Plant Variety Protection Office, a unit of the Agricultural Marketing Service, United States Department of Agriculture, administers the Plant Variety Protection Act by receiving applications and issuing certificates for the protected variety. The holder of the certificate then "owns" that variety for a specified number of years. The United States Patent and Trademark Office issues patents to individuals who invent a product or process that is novel. The courts and the Patent Office have decided that a living organism or a part of an organism may be patented. If a gene is patented, then the patent holder "owns" that gene for a specified number of years. In recent years, many patents have been issued for genes, such as those used in transgenic plants, but at present there are no transgenic peanut varieties. Neither the Plant Variety Protection Office nor the Patent and Trademark Office enforce compliance of the laws. The holder of the certificate for a protected variety or for a patent must take the responsibility to protect their rights through civil action for any alleged infringements.

One purpose of variety protection is to allow the developer a period of years of exclusive rights to recoup costs of research and development of new varieties. Without such incentives, there would be only limited development of improved varieties. Variety protection is available to public or governmental, as well as private developers of new varieties. The developer provides proof to the regulating agency that the new variety is different

1. This document is SS-AGR-186, one of a series of the Agronomy Department, Florida Cooperative Extension Service, Institute of Food and Agricultural Sciences, University of Florida. Original publication date November 2002. Visit the EDIS Web Site at http://edis.ifas.ufl.edu.

2. E. B. Whitty, professor, Agronomy Department, Cooperative Extension Service, Institute of Food and Agricultural Sciences, University of Florida, Gainesville, FL 32611.

The use of trade names in this publication is solely for the purpose of providing specific information. UF/IFAS does not guarantee or warranty the products named, and references to them in this publication does not signify our approval to the exclusion of other products of suitable composition. 
from any other, and if the application is approved, a certificate is issued. Only the holder of the certificate can give permission to others to propagate and sell the protected variety. The holder of a utility patent for a specific gene can use that gene to develop new varieties or he may give permission to others to use the gene to develop their own varieties. Permission to propagate or sell seed of a protected or patented variety is normally conveyed through contracts that include licenses, royalty payments, or other contracts.

Perhaps the most important purpose of variety protection and patent laws are to maintain genetic purity and help ensure that quality seed are made available to growers. While quality seed are necessary for purchasers to obtain good stands and produce satisfactory crops, genetic purity of high oleic peanuts is especially important to the consumer and therefore the entire peanut industry. If high oleic peanuts become mixed with other varieties, the possible health benefits of high oleic chemistry to consumers and the shelf life are compromised. It would take only a few rancid kernels to ruin the taste of an entire batch of peanuts.

It is not the purpose of variety protection or patents to prevent the planting of protected varieties, but rather to encourage their use because of desirable characteristics. The use of licensing agreements and royalty payments are the means that make the protected varieties available to the public, while providing a means to continue to fund breeding and variety development programs. Current seed production practices and certification procedures are the best means of insuring not only quality seed for the farmer, but may also help insure the integrity of the peanut industry.

\section{Plant Variety Protection}

The original Plant Variety Protection Act was enacted by Congress in 1970. Under this law a farmer could save seed of a protected variety to plant back the same acreage on his own farm, as well as any rented or leased land. If plans changed between harvest of the seed and the next planting, the farmer could sell the saved seed, but the total quantity sold could not exceed the amount needed to plant his holdings, again limited to the number of acres in the original planting. In 1994 the law was amended so that seed of varieties protected after April 4, 1995 could not be sold to others without permission of the variety owner, but the farmer could still plant them on his own farm or rented land. To do otherwise would be an infringement of variety protection and the farmer could be subject to civil action.

In addition to the farmer, anyone who cleaned, shelled, bagged, or stored the seed of the protected variety in quantities greater than that needed by the farmer to plant his own holdings would also be infringing on variety protection and therefore subject to civil action. The variety owner would be required to initiate any civil action. The custom operator who shells, cleans, bags, or stores seed may wish to have the grower sign a statement as to the variety, where it was grown, and that the peanuts will not be sold for planting purposes. It may also be useful to save a small sample of the unprocessed seed for testing if a claim of infringement is made.

At present it is believed that all commonly grown peanut varieties, except Florunner, are covered by plant variety protection. The seed tag on the original bag of seed would provide information as to plant variety protection. More information, including a list of varieties that are currently under variety protection, can be found through the Plant Variety Protection Office web site: http://www.ams.usda.gov/science/PVPO/pvp.htm.

\section{Utility Patents}

Patents are issued to anyone who invents a product or process that is novel, meaning that no other person has made, sold, or published a description of the product or process prior to the application to the United States Patent and Trademark Office. This office may also issue plant patents for asexually propagated varieties, but this has no impact on peanuts or other plants propagated by seed. With the advent of genetically modified or transgenic plants, the use of patents for genes that are transferred from one species to another has become common. Examples include those genes that have been introduced into cotton, soybeans, corn, and other crops to enable them to resist damage from certain 
herbicides or to provide protection from insects.

While there are no transgenic peanut varieties currently available, the high oleic characteristic was discovered and incorporated into peanuts by the University of Florida and others. There are three patents that cover seed, products, and oil from high oleic peanuts, with the University of Florida Research Foundation being the owner of the patents. These patent numbers are 5,922,390, 6,063,984, and $6,121,472$, and the full description of the three patents can be found through the patent office web site: http://www.uspto.gov.

The six varieties released by the University of Florida that have the high oleic characteristic include SunOleic 95R, SunOleic 97R, Andru II, GP-1, Hull, and Norden. This utility patent also covers varieties released by other individuals, agencies, or companies that contain the high oleic characteristic, such as Flavor Runner 458, GK 7 Hi-Oleic, AT 201, VC 2, and Georgia Hi-Oleic. These varieties that contain the patented high oleic characteristic are also protected, or likely will be protected, under the Plant Variety Protection Act. Any additional varieties of high oleic peanuts, as well as any high oleic peanuts imported into this country, would also be subject to the patents. Permission from the University of Florida Research Foundation, usually through licensing agreements and royalty payments, are needed to use the high oleic peanuts. Information can be obtained from: University of Florida, Office of Technology Licensing, Attn: Bruce Clary, PO Box 115500, Gainesville, FL 32611, or by telephone at 352-392-6393. Procedures are available to determine if peanuts contain the high oleic characteristic.

Unlike the plant variety protection program, there are no provisions for farmers to save seed of high oleic peanut varieties, even for their own use. Likewise custom shelling, cleaning, or storage of high oleic peanuts would be an infringement of the patent, even if the custom operator is not aware that the seed being handled are patented. The custom operator should protect his business from being charged with patent infringement by requiring the grower requesting his services to provide identity of the variety and where it was grown, and other documentation and agreements to prevent or reduce the likelihood of civil action. It may be useful in case of any patent infringement claims, if a small sample of unprocessed seed is saved and clearly labeled with pertinent information, including the grower's signature.

\section{Conclusion}

The above comments are intended to provide Florida growers with information about the effect plant variety protection and patent laws could have on plans to save peanut seed. Buyers of peanut seed should be sure that they purchase certified seed of known varieties and avoid "brown bag" seed that has no proof of variety, purity, or quality. Even though peanut seed prices may be lower than in the past, seed costs will still be a major part of the production costs. A poor stand will cause losses well beyond the cost of seed, especially where there is pressure from tomato spotted wilt virus.

Royalty payments on protected or patented seed would be a low-cost means of ensuring that you have quality seed, as well as promoting the continuation of development and release of improved varieties. The seed certification and crop improvement programs that are currently in place were also developed to help ensure quality seed for the grower and promote the development of new and improved varieties. Variety protection and patents are just additional steps in this process. Growers who wish to be seed producers should do so through a seed company or agency that is otherwise approved to propagate and sell protected or patented seed. For information on practices for production of quality peanut seed, see Agronomy Fact Sheet SS-AGR-187 Producing Quality Peanut Seed. 